\title{
Women of Twilight
}

\author{
KERRY KIDD
}

Women of Twilight (Daniel Angel, i952) was adapted from the play of the same name by Sylvia Rayman. The play was first performed at the Embassy Theatre, London, in July I95I, going on to the Vaudeville Theatre. Theatre World Annual called the stage set 'painfully squalid' and many people would have applied the phrase to the piece as a whole. It might have been used, too, of J. Lee Thompson's Yield to the Night a few years later in 1956 . It is a gritty and still shocking portrayal of the lives of those 'women of twilight' who, mostly as a consequence of unmarried pregnancy, find themselves shunned by respectable society, unable to find homes and prey to exploitation by 'baby-farmers' and unscrupulous landlords. A melodramatic opening finds pregnant Viviane (sic) (Renée Ray) searching for accommodation after her boyfriend Jerry (a cocktail of macho aggression and petulant vulnerability created by Laurence Harvey) is arrested for murder. Repeatedly recognised and rejected by landladies, Viviane eventually sees and answers the advertisement 'Room To Let, No. 4 Albion Road, No References Required'. It turns out to be a boarding-house for unmarried mothers, run by unscrupulous and tyrannical landlady Helen Allistair (Freda Jackson). Squalid and overcrowded, it nonetheless functions for Viviane as an anonymous place of sanctuary, where she can temporarily conceal herself from the prying gaze of the outside world. Whilst she is there, Jerry is sentenced to death and executed. Initially, her despair at losing him means that she is lost in her own misery and able to ignore the blatant exploitation surrounding her. Less fortunate is Christine (Lois Maxwell), who arrives for what she hopes will be 'just one night' and is horror-struck at the conditions in which she is forced to live. As the incidents of brutality and neglect increase, Rosie's (Joan Dowling) baby is announced by the

\footnotetext{
I was a graduate student in the English Literature Department at Sheffield University in 200I where I completed a doctoral thesis on the Royal Court Theatre and British culture in the late 1950s and early I960s. I have been actively involved in theatre work, in Africa and in Britain. I am currently working on a research project at Nottingham University on the effects of TV on its audiences. Kerry Kidd
} 
'clinic' to be suffering from malnutrition, and Mrs Allistair tries to make Viviane sell both her story and her child, revealing herself as an illegal babyfarmer. (She also confiscates her bracelet, a present from Jerry and symbol of her earlier happiness.) Next Mrs Allistair is instrumental in the death of Christine's child, whom Christine has left in Viviane's care: Mrs Allistair refuses to call a doctor, the baby slips into a coma and dies in Viviane's arms, just after Christine has returned. Gradually, these events awaken Viviane from her grief and she comes to protest repeatedly against this exploitative rule. Mrs Allistair blames Viviane for the baby's death, accusing her of neglect. Incensed, Viviane threatens to report Mrs Allistair to the authorities, but is prevented by Allistair's reminder that, as a criminal associate, she is unlikely to be believed. Shortly afterwards she hears a rumour that Allistair has not only farmed babies, but killed them: she confronts Allistair with the truth, and when Mrs Allistair sees she will not be bullied into silence any longer, she pushes Viviane down the stairs and leaves her for dead. However, Viviane is saved by one of the other girls, returning early from an evening outing; she survives, a nurse caring for her hears her story and in the last minutes of the film Mrs Allistair is arrested. Meanwhile, Christine's boyfriend has returned and married her. Unable to have children of her own, she adopts Viviane's child. The film ends with the baby in Christine's arms, reclaimed for respectability, while Viviane lies pallid but smiling on the bed.

The title of both play and film is doubly apt. Women of Twilight hovers uneasily in the twilight areas of post-war British society, but also in the grey area between two sets of competing and unresolved moralities. On the one hand, it has a liberal and progressive agenda, depicting criminality sympathetically, attempting to present a realistic and unsentimental view of contemporary Britain, and critical of the suffering imposed on young girls by society's attempt to preserve respectability at all costs. One of the more poignant touches is the moment where Sally (Dorothy Gordon) complains wistfully, 'I'm sure Daddy wouldn't let me stay here if he knew', the obvious point being that, having been cast out, Daddy neither knows nor cares how she lives. Women of Twilight thus accuses contemporary Britain of negligence, and lays the blame for these girls' suffering at the door of the contemporary social prejudice and hypocrisy which leaves them with nowhere else to go.

On the other hand, in both form and theme the film is consciously melodramatic, casting Helen Allistair as the villain of the piece whose abuse and exploitation are eventually appropriately punished. As a consequence the film clearly and honestly depicts contemporary abuses, but seems unsure whether to blame respectable social prejudice, more simplistic caricatures of villainy or even, implicitly, the sexual behaviour of the girls themselves. 
This implication was deliberately strengthened by the censorship authorities. In its textual interventions on the play text, the Lord Chamberlain's office came firmly down on the side of respectability and a sternly moralistic interpretation, demanding that the bleak line 'There is nothing wrong in being raped' be removed. In preparing the film, the British Board of Film Classifications made similar requests. Of particular note is the insistence that the phrases 'I was raped' and 'I would never have let it go so far' be cut. (See Tony Aldgate's 'Women of Twilight, Cosh Boy and the Advent of the X Certificate' in the Journal of Popular British Cinema for March 2000.) Such omissions suggest a strong desire on the part of both censorship bodies to simplify the women's plight, and render it more compatible with conceptions of unmarried motherhood as bad. For all her obvious sympathy with the plight of such vulnerable women, Rayman's original script also implies a degree of agreement with the moralistic view. This is best seen in the startlingly saccharine ending, where Viviane is unproblematically delighted to give up her child for the chance that it may grow up respectable and herself accuses her child of bearing potentially criminal genes, suggesting an attempt to reclaim the film for a respectable moral agenda and audience. This ending restores the morality of marriage and marks the final stages of Viviane's 'redemption' from social alienation and personal despair.

This despair is marked in the film by repeated visual reference to the iconography of imprisonment. We are never shown Jerry's prison cell, only his meetings with Viviane; but their moving final conversation through a glass window is echoed on the morning of his death, when Viviane looks out of the boarding-house window and the shadow of bars falls across her chest. Similarly, on Christine's first night in the house, when Viviane tells her she won't be able to get out and had better get used to the place, the light is switched out and shadows of prison bars fall across the bed. Most of the film is shot indoors, reinforcing the claustrophobic sensation of being caged in.

Nor is the final escape all that it seems. The inescapable plight of these 'twilight women', and the prison-like atmosphere in which they live, is reinforced in the final frame of the film as the camera cuts from Christine's verve and energy to the sickly Viviane's face on a white sheet. No longer confined by shadowy bars, Viviane nonetheless appears critically weakened. Unlike Christine, who can be rescued by marriage, she is only able to escape the 'twilight' of despair and alienation by renunciation. The central ambiguities of the film are emphasised in this final frame as she twists Jerry's bracelet, evocative of both happiness and grief. The giving away of her child has been presented as 'redeeming' her; but as she lies on the pillow, her stillness and pallor suggest that it is a kind of death, too. 